Britain, Italy, Netherlands, Norway (also representing Sweden), Poland and the Occupied Zones of Germany. Observers from the United States Weather Bureau and the International Civil Aviation Organisation were also present. Unhappily, the Danish delegate and his secretary were killed in an air collision over Northolt on the day before the conference opened.

In an address of welcome to the delegates the Secretary of State for Air referred to the growing importance of meteorology to economic problems, and he directed attention to the accuracy of modern weather forecasts-a fact which is frequently forgotten by the public, who tend to stress the occasional failures. Rapid dissemination of weather reports is vital to forecasting. Hitherto the international exchange of reports has been made primarily by wireless telegraphy, but in recent years high-speed teleprinters have been introduced to link several of the countries in western Europe. The conference discussed measures for increasing the efficiency of this international meteorological teleprinter network and for extending it to the countries of central and eastern Europe. For exchanging weather information between Europe and North America, high-speed radio teleprinters are to be used, although it will be necessary to retain a trans-Atlantic cable link as a standby for use when radio fade-outs render the radio-teleprinter channel inoperative. The conference recommended that Great Britain should provide the European terminal for these trans-Atlantic exchanges and should also be responsible for disseminating the American reports throughout Europe by wireless telegraphy and by the European land-line teleprinter network. Great Britain already transmits in highpower broadcasts from Rugby a 'European collective' message, which gives a selection of European weather reports and can be heard throughout the northern hemisphere.

\section{Evolution of the Gene}

Prof. A. H. Sturtevant discusses one of the most pressing problems of biology in a recent issue of the American Scientist $(34,225 ; 1948)$. It has been a mystery how new heritable material for the production of new characters originates. When Harland, as the result of his work on cotton, concluded that homology of parts in related species is not correlated with the homology of genes which produce them, another reason was given for disbelief in the value of homology for biological analysis. Sturtevant challenges this view and points out that the polyploid nature of cotton permits the differentiation of two sets of genes in the amphidiploids after their creation. Hence, in one species, one set of genes may control some characters, leaving the other free for differentiation. In a different species the reverse takes place. Sturtevant compares the characters in different species of Drosophila and suggests that two organs are homologous if they are conditioned by homologous genes. This implies degrees of homology, since genes may vary from being identical (being allelomorphic mutants), partly homologous to non-homologous. Homology therefore becomes relational and amenable to mathematical treatment rather than absolute.

Sturtevant points out that in a diploid organism all the genes are functional in that the characters they affect are subject to selection. An alteration in any one of them will give rise to a new phenotype. Therefore these genes cannot be spared for other purposes. If, on the other hand, some genes are carried on duplications, these will be surplus to the requirement of the organism and could vary to wide limits without an immediate effect on the individual or even its progeny. He therefore sees a source for new hereditary material in the duplications which constantly occur in most, if not all, living organisms.

\section{Hæmophilia in Dogs}

F. B. Hutt, C. G. Rickard and R. A. Field ( $J$. Hered., 39, 3 ; 1948) describe the discovery of a sex-linked hæmophilia in dogs. This shows as a lameness and by swellings in various parts of the body when the puppy is six weeks old. Examination showed that the lameness was due to hæmorrhage at the joints. Of seventeen puppies which have been recognized as hæmophilics, not one has been raised to maturity. Several tests for hæmophilia in man were applied to these dogs and were found to give positive results. The breeding histories of the parents of the puppies were known; as a result, it was easily seen that the condition was due to a sex-linked recessive gene called $h$. The importance of the discovery lies in the fact that the comparative physiology of dog and man is well known, and the condition will be of value in research. It is noteworthy that this case in dogs is one of the few sex. linked genes in mammals other than man where seven or eight sex-linked characters are known. The pig has an inherited hæmophilia; but this is controlled by a recessive gene on an autosome. It is probable that paralytic or lame puppies which were destroyed in the past were in reality sometimes hæmophilic. It would be desirable to discover whether any hæmo. philic puppies survive to maturity ; on the different genetic backgrounds of different breeds, the recessive gene may not always have a lethal effect.

\section{Uganda Forestry Department Report}

THE report for the year ended December 31, 1946, of the Uganda Forestry Department has recently been issued (Govt. Printer, Entebbe. 1s. 6d.). The following quotation from a report on forestry in Uganda, by the late Prof. R. S. Troup in 1922, is given in an opening paragraph. "The percentage of timber forest in Uganda is very small compared with that of most timber-producing countries. . . . There does not, however, appear to be any real cause for alarm, provided the existing forest area is strictly maintained, and all accessible forests are brought under systematic management. ... The preparation of forest Working Plans should be pushed on in all forests which are accessible to regular working. . . . Without Working Plans systematized work is impossible, and there is a strong risk of the forests being overworked and eventually rendered valueless." Uganda is one of the few departments in the Colonial Forest Services which has printed, published and circulated outside the Protectorate a working plan, with several others in hand. This plan is for the Budongo Forest and it undoubtedly saved that forest during the War. It has now been accurately revised for the second period of ten years, 1945-54. The Buganda Forests were exploited heavily during the War in the absence of a working plan, as in so many other parts of the British Empire and elsewhere in the world. The yield is now carefully controlled. The forest policy for Uganda is also being implemented by the systematic reservation of all main watersheds. This annual report shows that forestry and its requirements are thoroughly under. stood in Uganda. 